\title{
ANALISA PENGARUH RASIO KEUANGAN TERHADAP PROFITABILITAS PADA PERUSAHAAN PERBANKAN PERIODE 2016 - 2018
}

\author{
Devi Nurhasanah \\ Maryono \\ devihasanah21@yahoo.com \\ maryono@edu.unisbank.ac.id
}

\begin{abstract}
The purpose of this study is to examine and analyze the effect of financial ratios analyzed in this study are asset adequacy ratios, non-performing loans, and profitability ratios using the Capital Adequacy Ratio (CAR), Non Performing Loan variables (NPL), Net Interest Margin (NIM), Loan to Deposit Ratio (LDR) and Return On Assets (ROA) in banking companies listed on the IDX for the 2016 - 2018 period. This study's population were all banking companies listed on the IDX for the 2016- 2018 period. The sampling method used was purposive sampling with a sample size of 40 banking companies. This analysis tool has used multiple linear regression. The results of these study are NIM has a positive effect on ROA, NPL has a negative effect on ROA, while CAR and LDR have no effect on ROA in banking companies listed on the IDX for the 2016 - 2018 period.
\end{abstract}

\section{Keywords: Capital Adequacy Ratio, Non Performing Loan, Net Interest Margin, Loan to Deposit Ratio, Return On Assets}

\begin{abstract}
Abstrak: Penelitian ini bertujuan untuk menguji dan menganalisis pengaruh rasio keuangan terhadap profitabilitas perusahaan perbankan. Rasio keuangan yang digunakan antara lain variabel rasio kecukupan modal (CAR), variabel kredit bermasalah (NPL), margin bunga bersih (NIM), rasio pinjaman terhadap simpanan (LDR) bank dan return on asset (ROA) untuk perusahaan yang terdaftar di BEI 2016-2018. Populasi penelitian ini adalah seluruh perusahaan perbankan yang terdaftar di BEI antara tahun 2016 hingga 2018. Metode pengambilan sampel yang digunakan adalah purposive sampling, dengan jumlah sampel sebanyak 40 perusahaan perbankan. Alat analisis ini menggunakan regresi linier berganda. Hasil penelitian ini menunjukkan bahwa antara tahun 2016 dan 2018, diantara bank yang terdaftar di BEI, NIM berpengaruh positif terhadap ROA, kredit bermasalah berpengaruh negatif terhadap ROA, dan CAR dan LDR tidak berpengaruh terhadap ROA..
\end{abstract}

\section{Kata kunci: Capital Adequacy Ratio, Non Performing Loan, Net Interest Margin, Loan to Deposit Ratio, Return On Assets}

\section{PENDAHULUAN}

Perusahaan yang memberikan layanan keuangan kepada semua sektor masyarakat disebut bank. Secara umum, fungsi utama bank adalah menghimpun dana dari masyarakat dan mengarahkannya kembali ke publik. Hal ini menunjukkan bahwa fungsi bank umum adalah memberikan layanan dalam bisnis pembayaran. Mengingat pentingnya peran bank dalam perekonomian dan dampak kegagalan usaha bank terhadap perekonomian, maka perlu dilakukan serangkaian analisis untuk mengetahui permasalahan dalam bisnis perbankan sehingga dapat memprediksi kegagalan bank dan menjaga kesehatannya. Ini dapat dianalisis dengan menganalisis dan menghitung rasio kinerja keuangan. 
Undang-Undang Perbankan Nomor 10 tahun 1998 juga menegaskan bahwa bank-bank di Indonesia memiliki hak untuk mengevaluasi kinerja bank, yang dapat dilakukan dengan cara menganalisis laporan keuangannya untuk menentukan dan menerapkan strategi pengawasan bank. Kesehatan bank dapat diukur secara kuantitatif atau kualitatif dengan mengevaluasi kesehatan bank. Bagi bank, hasil akhir evaluasi kondisi bank dapat digunakan sebagai alat untuk menentukan strategi bisnis ke depan. Peran bank sebagai intermediasi menuntut kinerja keuangan yang sehat agar dapat bertahan dan bersaing di industri perbankan sehingga mendorong perkembangan industri perbankan. Perkembangan sektor ekonomi Indonesia, dalam beberapa tahun ke depan berada dalam era pasar bebas, industri perbankan khususnya bank komersial dan swasta Indonesia harus menghadapi persaingan yang semakin ketat. Oleh karena itu, perlu mempertimbangkan strategi yang sesuai untuk industri perbankan ke depan, yang nantinya dapat digunakan sebagai sarana untuk memperoleh keunggulan bersaing (Siamat, 2005).

Tingkat kesehatan suatu bank dapat dinilai dari beberapa indikator. Variabel atau indikator yang digunakan sebagai dasar evaluasi adalah laporan keuangan perusahaan. Dari laporan keuangan, banyak rasio keuangan yang biasa digunakan sebagai dasar untuk menilai tingkat kesehatan bank dapat dihitung. Hasil analisis laporan keuangan dapat digunakan untuk menjelaskan berbagai hubungan kunci dan tren, serta dapat memberikan dasar untuk mempertimbangkan potensi kesuksesan perusahaan di masa depan (Almilia dan Herdiningtyas, 2005). Fokusnya adalah pada kemampuan perusahaan untuk menghasilkan pendapatan dalam aktivitas perusahaan. Oleh karena itu, dalam penelitian ini ROA digunakan sebagai indikator untuk mengukur kinerja bank. Alasan dipilihnya Return on Assets (ROA) sebagai ukuran kinerja adalah Return on Assets digunakan untuk mengukur efektivitas bank dalam menggunakan asetnya untuk menghasilkan laba. ROA adalah rasio antara laba sebelum pajak dan total aset. Semakin besar ROA maka semakin baik kinerja keuangannya, karena semakin tinggi tingkat pengembaliannya maka semakin besar pula ROAnya maka semakin tinggi pula profitabilitas perusahaan.

Variabel yang mempengaruhi ROA adalah CAR, NPL, NIM dan LDR. Rasio kecukupan modal mencerminkan kecukupan permodalan bank, semakin tinggi rasio kecukupan modal maka semakin tinggi modal aset produktif, semakin rendah biaya modal, dan semakin tinggi tingkat pengembalian aset bank. Kredit bermasalah menunjukkan tingkat kredit bermasalah secara total kredit. Semakin tinggi rasio kredit bermasalah maka semakin tinggi kredit bermasalah bank, sehingga dana bank dapat menurunkan ROA. NIM menunjukkan kemampuannya untuk menghasilkan pendapatan dari bunga dengan melihat kinerja bank pada jalur kredit, sedangkan LDR mencerminkan kemampuan bank untuk menggunakan dana pihak ketiga untuk menghasilkan ROA. Fenomena yang terjadi dalam industri perbankan adalah kinerja keuangan yang dimiliki oleh industri perbankan yang semakin menurun yang dibuktikan dengan peningkatan kinerja perbankan. Permasalahan ini dapat terjadi karena ekosistem usaha yang sedang mengalami pelemahan dari seluruh sektor dan kondisi ekonomi global yang cenderung lesu yang mempengaruhi kondisi bisnis perbankan secara keseluruhan.

Berdasarkan data Statistik Perbankan Indonesia dari OJK dapat diketahui bahwa terjadi fenomena pada perusahaan perbankan di Indonesia dimana nilai ROA perusahaan perbankan sebesar 2,23 pada tahun 2016 dan pada tahun 2017 mengalami peningkatan sebesar 2,45. Sedangkan pada tahun 2018 juga mengalami peningkatan sebesar 2,55 yang secara rata-rata industri mengalami peningkatan, Kondisi tersebut menunjukkan efektifitas bank menggunakan asetnya untuk menghasilkan pendapatan. Karena semakin tinggi nilai ROA maka semakin baik pula kemampuan bank dalam menghasilkan laba. Pertama, ada beberapa hasil penelitian terdahulu yang berkaitan dengan faktorfaktor yang mempengaruhi Return on Assets (ROA), namun memiliki hasil yang masih berbeda-beda antara lain yaitu menurut Dewi (2017), dan Pinasti dan Mustikawati (2018) CAR berpengaruh negatif 
tidak signifikan terhadap ROA, menurut Avrita dan Pangestuti (2016), dan menurut Dewi dan Suryanawa (2018) CAR berpengaruh signifikan negatif terhadap ROA, menurut Arifianto (2016) CAR berpengaruh positif dan signifikan terhadap ROA. Menurut Dewi dkk, (2015), dan Fajari dan Sunarto (2017) CAR tidak berpengaruh terhadap ROA.

Kedua, faktor terkait Non Performing Loan (NPL) yang NPL berpengaruh negatif signifikan terhadap ROA adalah dalam penelitiannya Dewi (2017), dan Fajari dan Sunarto (2017), menurut Pinasti dan Mustikawati (2018) NPL memiliki pengaruh positif tidak signifikan terhadap ROA. Menurut Avrita dan Pangestuti (2016) NPL memiliki pengaruh negatif tidak signifikan terhadap ROA, menurut Dewi dkk, (2015), Dewi dan Suryanawa (2018), dan Arifianto (2016) NPL berpengaruh negatif terhadap ROA, sedangkan menurut Alifah (2014) NPL tidak berpengaruh terhadap ROA.

Ketiga, faktor terkait Net Interest Margin (NIM) yang mempengaruhi ROA adalah dalam penelitiannya Dewi (2017) NIM berpengaruh negatif tidak signifikan terhadap ROA, sedangkan menurut Pinasti dan Mustikawati (2018), Avrita dan Pangestuti (2016), Dewi, dkk (2015), dan Arifianto (2016) NIM berpengaruh positif signifikan terhadap ROA. Keempat, faktor terkait Loan to Deposit Ratio (LDR) yang mempengaruhi ROA dalam penelitiannya Dewi (2017), Dewi dan Suryanawa (2018), dan Alifah (2014) LDR berpengaruh positif signifikan terhadap ROA, menurut Pinasti dan Mustikawati (2018) LDR berpengaruh negatif tidak signifikan terhadap ROA, menurut Avrita dan Pangestuti (2016) LDR berpengaruh signifikan negatif terhadap ROA, sedangkan menurut Dewi, dkk (2015), Fajari dan Sunarto, Arifianto (2016) LDR tidak berpengaruh terhadap ROA.

Penelitian ini menyangkut objek penelitian berupa perusahaan perbankan yang terdaftar di Bursa Efek Indonesia (BEI) tahun 2016-2018. Variabel yang digunakan dalam penelitian ini adalah CAR, NPL, NIM dan LDR untuk ROA. Berkaitan dengan hal tersebut maka dilakukan penelitian berjudul "Dampak Rasio Kecukupan Modal Bank, Rasio Pinjaman terhadap Simpanan, Marjin Bunga Bersih dan Kredit Macet terhadap Return on Assets Perusahaan Perbankan Tahun 2016-2018".

\section{Bank}

Undang-Undang Perbankan Nomor 10 Tahun 1998 mendefinisikan bank sebagai badan usaha yang menghimpun dana dari masyarakat dalam bentuk simpanan dan menyalurkan dana tersebut dalam bentuk kredit atau bentuk lain untuk meningkatkan taraf hidup masyarakat. Hal ini sesuai dengan definisi bank yang dikemukakan oleh Kasmir (2008). Sesuai dengan Peraturan Otoritas Jasa Keuangan Nomor 4 Tahun 2016 Tentang Penilaian Tingkat Kesehatan Bank Umum, menyebutkan:

1. Profil risiko: Penilaian faktor profil risiko adalah penilaian risiko yang melekat pada bisnis Bank Dunia dan kualitas manajemen risiko. Delapan (delapan) risiko yang harus dinilai adalah: risiko kredit; risiko pasar; risiko likuiditas; risiko operasional; risiko hukum dan risiko strategis; risiko kepatuhan; dan risiko reputasi. Profil risiko tersebut dapat diukur dengan mengukur risiko kredit dengan rasio kredit bermasalah (NPL).

2. Good Corporate Governance (GCG); evaluasi wajib unsur-unsur GCG merupakan evaluasi pelaksanaan prinsip-prinsip GCG oleh manajemen bank.

3. Leaseability (pendapatan); kewajiban untuk mengevaluasi profitabilitas (return) meliputi evaluasi profitabilitas bank (return) kinerja, sumber keuntungan (return) dan profitabilitas (return sustainability). Gunakan rasio margin laba bersih (NPM), margin laba kotor (GPM), laba atas aset $(\mathrm{ROA})$, laba atas aset bersih (ROE) dan tingkat bunga bersih (NIM) untuk mengukur pendapatan.

4. Modal (modal). Penilaian Faktor permodalan meliputi penilaian rasio kecukupan modal dan pengelolaan modal. Rasio yang mengukur rasio kecukupan modal suatu bank adalah rasio kecukupan modal (CAR). 


\section{Rasio Kecukupan Modal (CAR)}

CAR merupakan rasio kinerja bank, yang digunakan untuk mengukur rasio kecukupan modal bank untuk mendukung aset yang mengandung atau merupakan risiko (seperti kredit). CAR menunjukkan bahwa bank memiliki kemampuan untuk mengkompensasi penurunan aset yang disebabkan oleh kerugian bank yang disebabkan oleh aset berisiko. (Taswan, 2010).

\section{Non Performing Loan (NPL)}

NPL adalah hasil pengembalian kredit dari deposan kepada bank, dengan kata lain NPL adalah tingkat kredit bermasalah bank. Kredit macet dapat diketahui dengan menghitung total pembiayaan dari pembiayaan tidak lancar. Jika suku bunga kredit macet rendah maka bank akan mendapat untung lebih banyak, sebaliknya jika suku bunga kredit macet tinggi maka bank akan mengalami kerugian akibat tingkat pengembalian kredit macet. (Taswan, 2010).

\section{Net Interest Margin (NIM)}

NIM digunakan untuk mengukur rasio kemampuan manajemen bank dalam mengelola aset produktifnya untuk menghasilkan pendapatan bunga bersih. Pendapatan bunga bersih diperoleh dari pendapatan bunga dikurangi beban bunga. Semakin besar rasionya maka semakin tinggi pendapatan bunga dari aset produktif yang dikelola bank sehingga mengurangi kemungkinan bank bermasalah. (Taswan, 2010).

\section{Rasio pinjaman terhadap simpanan (LDR)}

LDR adalah rasio yang mengukur hubungan antara jalur kredit dan dana yang digunakan dan modal publik. Semakin tinggi rasionya, semakin rendah likuiditas bank yang bersangkutan, yang membuat bank tersebut kemungkinan besar akan mendapat kesulitan. (Taswan, 2010).

\section{Laba atas Aset (ROA)}

ROA atau Return on Assets adalah rasio laba sebelum pajak terhadap total aset. Semakin tinggi tingkat pengembalian aset, semakin baik kinerja keuangannya, karena semakin tinggi tingkat pengembaliannya. NIM merupakan rasio yang digunakan untuk mengukur kemampuan manajemen bank dalam mengelola aset produktifnya untuk menghasilkan pendapatan bunga bersih. Pendapatan bunga bersih berasal dari pendapatan bunga dikurangi beban bunga. Semakin besar rasionya, semakin tinggi pendapatan bunga dari aset produktif yang dikelola bank, yang membuat kemungkinan bank bermasalah semakin kecil. (Taswan, 2010).

\section{Pengaruh CAR terhadap ROA}

Rasio kecukupan modal (CAR) adalah rasio yang digunakan untuk mengukur rasio kecukupan modal bank penunjang aset berisiko. Rasio kecukupan modal merupakan perhitungan rasio modal bank terhadap aset tertimbang menurut risiko (ATMR) (Taswan, 2010:166). Menurut Kasmir (2014:197), semakin tinggi rasio kecukupan modal maka semakin banyak kredit yang diberikan sehingga meningkatkan laba bank dan dengan demikian meningkatkan profitabilitas bank. Berdasarkan Surat Edaran yang dikeluarkan oleh Bank Indonesia Nomor 6/23/DPNP/2004 perihal Sistem Penilaian Tingkat Kesehatan Bank Umum, menyebutkan bahwa jika rasio kecukupan modal bank melebihi 12\%, maka kesehatan bank sangat sehat. Dalam penelitian yang dilakukan oleh Arifianto (2016), CAR berpengaruh positif dan signifikan terhadap ROA.

$\mathrm{H}_{1}$ : CAR berpengaruh positif terhadap ROA.

\section{Pengaruh NPL terhadap ROA}

Rasio kredit bermasalah merupakan rasio yang mengukur kemampuan manajemen bank dalam mengelola kredit bermasalah yang diberikan bank kepada nasabah atau bank lain. Kredit bermasalah diklasifikasikan sebagai kurang lancar, mencurigakan dan non-performing. Semakin tinggi rasionya maka semakin buruk kualitas kredit bank, yang akan meningkatkan jumlah kredit macet dan menimbulkan kerugian. Berdasarkan Surat Edaran yang dikeluarkan oleh Bank Indonesia Nomor 
6/23/DPNP/2004 perihal Sistem Penilaian Tingkat Kesehatan Bank Umum, menyebutkan jika rasio NPL $2 \%$ berarti kondisi bank baik, sedangkan rasio NPL 2\% s / d 5\% berarti kondisi bank baik. Dalam penelitian yang dilakukan oleh Dewi dkk, (2015), Dewi dan Suryanawa (2018) dan Arifianto (2016), kredit bermasalah berdampak negatif terhadap ROA.

$\mathrm{H}_{2}$ : Kredit bermasalah berdampak negatif terhadap ROA.

\section{Pengaruh NIM terhadap ROA}

Suku bunga bersih (NIM) merupakan salah satu indikator yang harus diperhatikan dalam menilai profitabilitas bank. Suku bunga bersih (NIM) merupakan rasio yang digunakan untuk mengukur kemampuan manajemen bank dalam mengelola aset penghasil pendapatan untuk menghasilkan pendapatan bunga bersih. Menurut Riyadi (2009: 21), NIM adalah rasio pendapatan bunga bank dikurangi biaya bunga bank dibagi rata-rata pendapatan aset, dan pendapatan bunga bersih diperoleh dari pendapatan bunga dikurangi beban bunga. Semakin tinggi rasio NIM, semakin baik kinerja bank dalam memperoleh pendapatan bunga. Semakin besar perbedaan antara pendapatan bunga dan beban bunga yang diperoleh maka semakin besar pula margin keuntungan yang diperoleh (Taswan, 2010). Dalam penelitian yang dilakukan oleh Pinasti dan Mustikawati (2018), Avrita dan Pangestuti (2016), Dewi dkk, (2015), NIM memiliki pengaruh positif signifikan terhadap ROA.

$\mathrm{H}_{3}$ : NIM berpengaruh positif terhadap ROA

\section{Pengaruh LDR terhadap ROA}

Loan to Deposit Ratio (LDR) adalah rasio yang membandingkan jumlah pinjaman dengan risiko likuiditas yang diterima bank. Menurut Kasmir (2014:225), LDR adalah rasio yang mengukur rasio jumlah kredit terhadap jumlah dana dan modal masyarakat yang digunakan. Semakin tinggi LDR maka semakin tinggi pula laba bank tersebut, bank yakin bahwa laba tersebut dapat memandu kredit dengan baik, sehingga peningkatan laba bank dapat meningkatkan kinerja bank. Peningkatan laba juga merupakan bagian dari ROA. Berdasarkan Surat Edaran yang dikeluarkan oleh Bank Indonesia Nomor 6/23/DPNP/2004 perihal Sistem Penilaian Tingkat Kesehatan Bank Umum, menyebutkan jika rasio pinjaman terhadap simpanan suatu bank $85 \%$ banding $100 \%$, maka bank tersebut dinyatakan sangat sehat. Dalam penelitian yang dilakukan oleh Dewi (2017), Dewi dan Suryanawa (2018) dan Alifah (2014), LDR memiliki pengaruh positif signifikan terhadap ROA.

$\mathrm{H}_{4}$ : LDR berpengaruh positif terhadap ROA.

\section{Model Penelitian}

Model penelitian yang dikembangkan dalam penelitian ini tampak pada gambar 1.

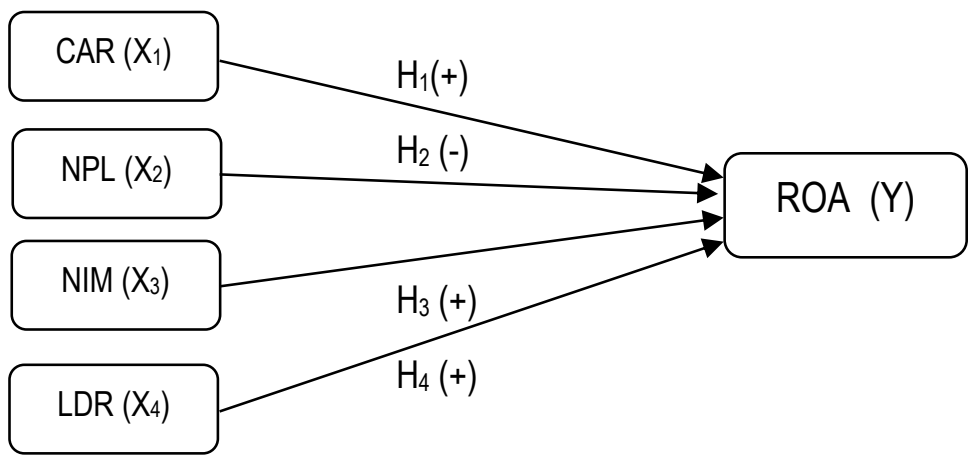

Gambar 1 Model Penelitian 


\section{METODE PENELITIAN \\ Populasi}

Jenis data pada penelitian ini adalah data sekunder yaitu data yang didapatkan dari hasil pencatatan atau dari pihak ketiga (Sugiyono, 2013). Sumber data sekunder ini adalah laporan keuangan publikasi perusahaan perbankan yang terdaftar di Bursa Efek Indonesia selama tahun 2016 sampai tahun 2018.

\section{Sampel}

Sampel merupakan suatu bagian dari populasi yang dipilih sebagai obyek penelitian oleh peneliti (Sugiyono, 2013:118). Pengambilan sampel dilakukan dengan menggunakan metode Purposive Sampling, yaitu teknik pengambilan sampel berdasarkan kelompok karakteristik khusus dari sampel yang dipilih (Sugiyono, 2013:124). Perusahaan perbankan yang menjadi sampel dalam penelitian ini adalah: 1. Perusahaan bank yang telah menerbitkan laporan keuangan selama tiga tahun berturut-turut untuk memastikan konsistensi data penelitian di Bursa Efek Indonesia dari tahun 2016 hingga 2018; 2.

Selama periode penelitian diperlukan perusahaan Bank dengan data yang lengkap.

\section{Variabel Penelitian dan Definisi Operasional}

\section{Capital Adequecy Ratio (CAR)}

CapitaL Adequacy Ratio digunakan sebagai variabel independen (X1), dan rasio kecukupan modal digunakan sebagai indikator permodalan, yaitu rasio kecukupan modal terendah di bank. Ini adalah rasio yang menunjukkan seberapa besar risiko (kredit, investasi, sekuritas, klaim pada bank lain) yang terkandung di semua aset bank selain memperoleh dana dari sumber selain bank yang perlu dibiayai melalui dana sendiri (Almillia dan Herdinigtyas, 2005). Berdasarkan Surat Keputusan Direktur Bank Indonesia No.30/12/KEP/DIR/1997 tentang Tata Cara Penilaian Tingkat Kesehatan Bank Umum, disebutkan nilai CAR tidak boleh $8 \%$. Rumus besarnya CAR adalah sebagai berikut:

CAR $=$ (Modal Sendiri) $/$ ATMR $\times 100 \%$

\section{Pinjaman bermasalah (NPL)}

Peraturan Bank Indonesia Nomor 17/11/PBI/2015 Tentang Perubahan Atas Peraturan Bank Indonesia Nomor 15/15/PBI/2013 Tentang Giro Wajib Minimum Bank Umum Dalam Rupiah dan Valuta Asing Bagi Bank Umum Konvensional, yang mengatur tentang perubahan persyaratan minimum simpanan Rupiah, Non Performing Loan (NPL) adalah Digunakan sebagai variabel independen (X2) Bagi bank umum dan bank umum devisa konvensional, kredit bermasalah mengacu pada rasio jumlah kredit terhadap kredit yang digolongkan kurang lancar, diragukan dan kredit macet. Rasio ini menunjukkan kemampuan manajemen bank dalam mengelola kredit bermasalah yang diberikan oleh bank, dalam hal ini kredit mengacu pada kredit kepada pihak ketiga, tidak termasuk kredit kepada bank lain. Berdasarkan Surat Edaran yang dikeluarkan oleh Bank Indonesia Nomor 6/23/DPNP/2004 Perihal Sistem Penilaian Tingkat Kesehatan Bank Umum, menyebutkan jika rasio NPL sebesar 2\% berarti kondisi bank baik, sedangkan rasio NPL $2 \%$ s / d 5\% berarti kondisi bank baik. Rasio kredit macet dirumuskan dengan:

$\mathrm{NPL}=($ Kredit Bermasalah / Kredit yang Disalurkan $) \times 100 \%$

\section{Margin bunga bersih (NIM)}

Suku bunga bersih (NIM) digunakan sebagai variabel independen (X3) Mengukur kemampuan manajemen bank dalam mengelola aset produktifnya untuk menghasilkan pendapatan bunga bersih. Pendapatan bunga bersih diperoleh dari pendapatan bunga dikurangi beban bunga. Semakin besar rasionya, semakin tinggi pendapatan bunga dari aset produktif yang dikelola bank, dan semakin kecil kemungkinan bank bermasalah. Surat Edaran Bank Indonesia Nomor 13/23/DPNP/2011 Perihal Perubahan atas Surat Edaran No. 5/21/DPNP Perihal Penerapan Manajemen Risiko Bagi Bank Umum, yang dikeluarkan tanggal 25 Oktober 2011 rumus margin bunga bersih adalah sebagai berikut: 
NIM = (Pendapatan Bunga Bersih / Rata-rata Pendapatan Aset) $\times 100 \%$

\section{Rasio pinjaman terhadap simpanan (LDR)}

Berdasarkan Peraturan Bank Indonesia Nomor 15/7/PBI/2013 Tentang Perubahan Kedua Atas Peraturan Bank Indonesia Nomor 12/19/PBI/2010 Tentang Giro Wajib Minimum Bank Umum Pada Bank Indonesia Dalam Rupiah dan Valuta Asing, loan to deposit ratio (LDR) diambil sebagai Variabel independen (X4) dan mata uang asing bank GWM seperti rupee umum dan tabungan domestik serta deposita berjangka. Menurut Kasmir (2014: 225), batas atas aman dari rasio pinjaman-ke-deposito sekitar $80 \%$. Namun, LDR maksimum dibatasi hingga 110\%. Rasio LDR diperoleh dengan cara membandingkan kredit dengan dana pihak ketiga Kredit yang digunakan mengacu pada jumlah kredit yang diberikan kepada pihak ketiga, tidak termasuk pinjaman yang diberikan kepada pihak lain. Sedangkan dana pihak ketiga merupakan giro, tabungan dan deposito, tidak termasuk rekening antar bank. Rumus besaran LDR adalah sebagai berikut:

LDR $=($ Kredit Diberikan $/$ Total Dana Pihak Ketiga $) \times 100 \%$

\section{Laba atas Aset (ROA)}

Return on Assets (ROA) digunakan sebagai variabel dependen $(\mathrm{Y})$, yaitu tingkat pengembalian yang digunakan untuk mengevaluasi atau mengukur efektivitas penggunaan bank dalam menghasilkan laba atas total aset perusahaan. Menurut Kasmir (2014: 201) Return on Assets merupakan rasio yang menunjukkan hasil dari total aset yang digunakan oleh perusahaan. Semakin besar nilai ROA maka semakin baik kinerja perusahaan, karena perusahaan mendapatkan return yang lebih banyak. Berdasarkan Surat Edaran Bank Indonesia Nomor 30/2/UPPB Tanggal 30 April 1997 Tentang Tatacara Penilaian Tingkat Kesehatan Bank Umum dan Surat Edaran BI No. 30/3/UPPB Tentang Tata Cara Penilaian Tingkat Kesehatan Bank Perkreditan Rakyat yang diundangkan pada tanggal 30 April 1997, apabila ROA suatu bank lebih dari 1.215\% maka harus ditetapkan standar kesehatannya. ROA dirumuskan sebagai berikut:

ROA = (Laba Sebelum Pajak / Total Aktiva) $\times 100 \%$

\section{HASIL DAN PEMBAHASAN}

\section{Analisis Deskriptif Statistik}

Berdasarkan tabel diatas terlihat bahwa variabel ROA mempunyai nilai rata-rata profitabilitas bank sebesar 1,29\% menunjukkan jika perusahaan perbankan dapat menghasilkan keuntungan sebesar 1,29\% dari aset yang dimilikinya. Hal ini menunjukkan bahwa pasar percaya bahwa perusahaan berkinerja baik karena masih mampu menghasilkan laba. Nilai standar deviasi yang lebih kecil dari nilai rata-rata menunjukkan bahwa data variabel profitabilitas bank cukup berbeda.

Variabel CAR mempunyai nilai Capital Adequacy Ratio sebesar 20,68\% yang bernilai lebih besar dari nilai minimal yang dipersyaratkan yaitu $8 \%$ sehingga dapat dinyatakan bahwa perusahaan perbankan memiliki kondisi permodalan yang sehat. Berdasarkan nilai standar deviasi sebesar 5,82\% yang lebih kecil dari nilai rata-ratanya dapat diketahui bahwa variasi data CAR kecil.

Rata-rata nilai kredit macet dari variabel NPL adalah 3,20\%. Sedangkan standar deviasi kredit macet sebesar $1,44 \%$. Hasil tersebut menunjukkan bahwa rata-rata kredit macet perusahaan perbankan menyumbang $3,2 \%$ dari total kredit. Rasio kredit bermasalah sebesar $3,2 \%$, lebih rendah dari standar Bank Indonesia 5\%, menunjukkan bahwa pengawasan risiko kreditnya baik.. Nilai standar deviasi yang lebih kecil dari rata-rata menunjukkan bahwa data pada variabel NPL tidak jauh berbeda.

Margin bunga bersih rata-rata dari variabel NIM adalah 4,97\%. Pada saat yang sama, standar deviasi dari tingkat bunga bersih yang menggambarkan distribusi data ke rata-rata adalah 1,54\%. Margin bunga bersih rata-rata sebesar $4,97 \%$ yang menunjukkan bahwa perusahaan perbankan 
memperoleh keuntungan dari penyediaan jasa bunga kredit. Nilai standar deviasi margin bunga bersih lebih kecil dari nilai rata-rata yang berarti perubahan margin bunga bersih kecil.

Rata-rata rasio pinjaman terhadap simpanan variabel LDR adalah $85,73 \%$. Sedangkan standar deviasi rasio pinjaman yang menggambarkan distribusi data terhadap rata-rata adalah $11,63 \%$. Rasio pinjaman terhadap deposito rata-rata adalah $85,73 \%$, yang masih lebih tinggi dari $78 \%$ dari batas bawah penerimaan penyimpan lokal dan lebih rendah dari $92 \%$ dari batas atas penerimaan penyimpan lokal, yang menunjukkan bahwa rata-rata alokasi pinjaman perbankan perusahaan cukup efektif. Sementara itu, standar deviasi yang lebih kecil dari rata-rata menunjukkan bahwa data variabel rasio pinjaman terhadap simpanan memiliki sedikit perubahan atau ukuran perusahaan sampel relatif sama.

Tabel 1 : Statistik Deskriptif

\begin{tabular}{|l|r|r|r|r|r|}
\hline & \multicolumn{1}{|c|}{ N } & Minimum & Maximum & \multicolumn{1}{c|}{ Mean } & Std. Deviation \\
\hline ROA & 98 & $-5,25$ & 4,00 & 1,2958 & 1,45472 \\
CAR & 98 & 3,21 & 39,46 & 20,6828 & 5,82450 \\
NPL & 98 &, 08 & 6,86 & 3,2065 & 1,44525 \\
NIM & 98 & 1,53 & 9,30 & 4,9607 & 1,54011 \\
LDR & 98 & 50,61 & 111,07 & 85,7312 & 11,63298 \\
Valid N & 98 & & & & \\
(listwise) & & & & & \\
\hline
\end{tabular}

Sumber: Data Diolah

1. Pengaruh CAR terhadap ROA bank

Berdasarkan ringkasan hasil pengujian hipotesis yang telah dilakukan, menunjukkan bahwa rasio kecukupan modal tidak berpengaruh terhadap profitabilitas perusahaan perbankan yang terdaftar di Bursa Efek Indonesia selama tahun 2016-2018. Rasio kecukupan modal memberi sinyal kepada investor tentang kesehatan perusahaan perbankan. Dalam penelitian ini ditemukan bahwa CAR tidak berpengaruh signifikan terhadap profitabilitas perusahaan bank karena didasarkan pada statistik deskripti diketahui bahwa perusahaan perbankan memiliki CAR dalam variasi yang kecil sehingga seluruh perusahaan perbankan sampel mampu memenuhi kebutuhan permodalannya untuk melakukan usaha. Dalam hal ini pemenuhan permodalan perusahaan perbankan yang merupakan jantung penggerak dari perusahaan perbankan telah berada di atas $8 \%$. Adanya kondisi tersebut membuat profitabilitas perusahaan perbankan bervariasi yang disebabkan oleh kondisi lain di luar permodalan perbankan. Hasil ini sesuai dengan penelitian Dewi dkk, (2015), Dewi (2017), Fajari dan Sunarto (2017), dan Pinasti dan Mustikawati (2018) yang menyatakan bahwa capital adequacy ratio tidak berpengaruh terhadap profitabilitas bank.

2. Dampak kredit macet terhadap pengembalian aset bank

Berdasarkan ringkasan hasil uji hipotesis yang dilakukan terhadap kredit macet berpengaruh negatif terhadap profitabilitas perusahaan perbankan yang terdaftar di Bursa Efek Indonesia selama tahun 2016-2018. Kredit macet adalah perbandingan antara kredit macet dengan total pengeluaran bank. Kredit merupakan salah satu cara bagi perusahaan perbankan untuk mendapatkan keuntungan dari operasional bisnisnya, karena bunga kredit merupakan sumber pendapatan utama bagi perusahaan perbankan. Dalam memberikan kreditnya, perusahaan perbankan juga perlu untuk memberlakukan prinsip kehati-hatian, sebab tanpa adanya prinsip kehati-hatian tersebut, maka perusahaan perbankan akan dapat mengalami permasalahan dimana kredit bermasalah yang terlambat pembayarannya hingga tidak terbayar meningkat. Peningkatan dari kredit bermasalah ini akan mengganggu cashflow perusahaan perbankan karena dengan semakin banyaknya kredit bermasalah 
maka profit perusahaan akan berkurang sebab pemasukan dari bunga kredit semakin mengalami penurunan. Hasil ini sesuai dengan penelitian menurut Dewi dkk, (2015), Arifianto (2016), Fajari dan Sunarto (2017), Dewi (2017), dan Dewi dan Suryanawa (2018), yang menyatakan bahwa non performing loan berpengaruh negatif terhadap profitabilitas bank.

3. Dampak NIM terhadap ROA bank

Berdasarkan rangkuman hasil uji hipotesis yang lengkap, terlihat bahwa NIM berpengaruh positif terhadap profitabilitas perusahaan perbankan yang terdaftar di Bursa Efek Indonesia selama periode 2016-2018. Net interest margin merupakan pengukuran akan kemampuan dari manajemen perusahaan perbankan untuk mengelola asetnya yang produktif dalam perputaran usaha perbankan untuk menghasilkan pendapatan dari bunga. Ketika aset produktif yang dikelola oleh perusahaan perbankan semakin besar, maka perusahaan perbankan akan memiliki sumber pendapatan yang cukup besar juga sehingga perusahaan perbankan memiliki kemungkinan lebih besar untuk menghasilkan profit. Peningkatan pendapatan bunga yang didapatkan dari pengelolaan aset produktif di bank membuat perusahaan perbankan meningkatkan profitabilitasnya secara keseluruhan.

Hasil Pengujian ini sesuai dengan penelitian Dewi dkk, (2015), Avrita dan Pangestuti (2016), Arifianto (2016), Fajari dan Sunarto (2017), Pinasti dan Mustikawati (2018) menyatakan bahwa net interest margin berpengaruh positif terhadap profitabilitas bank.

4. Pengaruh LDR terhadap ROA bank

Ringkasan hasil pengujian hipotesis yang telah lengkap, menunjukkan bahwa rasio pinjaman terhadap deposito tidak berpengaruh terhadap profitabilitas perusahaan perbankan yang terdaftar di Bursa Efek Indonesia selama tahun 2016-2018. Rasio pinjaman terhadap simpanan mengacu pada rasio jumlah kredit yang dikeluarkan oleh perusahaan bank dan dana yang diterima bank menjadi dana perusahaan bank.

Berdasarkan dari statistik deskriptif didapatkan hasil bahwa LDR untuk perusahaan perbankan memiliki nilai yang kurang bervariasi sehingga dapat dinyatakan dalam periode tersebut hampir semua perusahaan perbankan memiliki kemampuan likuiditas yang sama. Perusahaan perbankan dalam periode 2016-2018 sedang berusaha bertahan menghadapi situasi ekonomi yang cukup sulit, sehingga mau untuk mengucurkan sejumlah kredit, walaupun demikian, jumlah kredit yang diberikan rata-rata masih ada dalam batas wajar yaitu di antara 78\%-92\% sehingga perusahaan perbankan masih dalam batas aman. Kondisi perusahaan perbankan yang mengusahakan keamanan dan tetap konservatif dalam pengeluaran kredit menjadikan status likuiditas perusahaan perbankan bukan merupakan faktor penentu dalam menciptakan peningkatan profitabilitas perusahaan perbankan tersebut. Hasil ini sejalan dengan penelitian Dewi dkk, (2015), Arifianto (2016) dan Pinasti dan Mustikawati (2018) yang menunjukkan bahwa loan to deposit ratio tidak berpengaruh terhadap Return on Assets bank.

\section{PENUTUP}

Berdasarkan hasil penelitian yang telah diselesaikan, dapat ditarik kesimpulan sebagai berikut:

1. Rasio kecukupan modal (CAR) tidak akan mempengaruhi tingkat pengembalian aset bank yang terdaftar di Bursa Efek Indonesia dari tahun 2016 hingga 2018.

2. Selama tahun 2016-2018, kredit bermasalah berdampak negatif terhadap tingkat pengembalian aset perusahaan perbankan yang terdaftar di Bursa Efek Indonesia.

3. Dari tahun 2016 hingga 2018, hasil bunga bersih (NIM) berdampak positif terhadap tingkat pengembalian aset perusahaan perbankan yang terdaftar di Bursa Efek Indonesia.

4. Selama tahun 2016-2018 rasio pinjaman terhadap simpanan tidak berpengaruh terhadap pengembalian aset perusahaan perbankan yang terdaftar di Bursa Efek Indonesia.REKOMENDASI 
5. Untuk agenda penelitian selanjutnya direkomendasikan untuk menambah variabel internal bank maupun variabel eksternal bank seperti pertumbuhan ekonomi, tingkat inflasi, tingkat pengangguran atau variabel lain yang relevan.

\section{DAFTAR PUSTAKA:}

Alifah, Y., B. (2014). Pengaruh CAR, NPL, BOPO dan LDR pada Perusahaan Perbankan yang terdaftar di Bursa Efek Indonesia Periode 2009-2012. Skripsi. Yogyakarta: FE Universitas Negeri Yogyakarta.

Almilia, L. S. dan Herdiningtyas, W. (2005). Analisis Rasio CAMEL terhadap Prediksi Kondisi Bermasalah Pada Lembaga Perbankan Perioda 2000-2002. Jurnal Akuntansi dan Keuangan, 7(2), 131-147.

Arifianto, A. (2016). Pengaruh Capital Adequacy Ratio (CAR), Non Performing Loan (NPL), Biaya Operasional Pada Pendapatan Operasional (BOPO), Loan to Deposit Ratio (LDR), dan Net Interest Margin (NIM) Terhadap Profitabilitas Bank Umum Konvensional yang Terdaftar di Bursa Efek Indonesia. Skripsi. Yogyakarta: Universitas Negeri Yogyakarta.

Avrita, R. D., \& Pangestuti, I. R. D. (2016). Analisis Pengaruh CAR, NPL, LDR, NIM, dan BOPO Terhadap Profitabilitas Bank (Perbandingan Bank Umum Go Public dan Bank Umum Non Go Public Di Indonesia Periode Tahun 2011-2014). Diponegoro Journal of Management, 5(2), 366378.

Dewi, A., S. (2017). Pengaruh CAR, BOPO, NPL, NIM, dan LDR Terhadap ROA Pada Perusahaan Di Sektor Perbankan Yang Terdaftar Di BEI Periode 2012-2016. Jurnal Pundi, 1(3), 223- 236.

Dewi, M., D., K. \& Suryanawa I., K. (2018). Pengaruh Tingkat Suku Bunga, Profesi Nasabah Kredit, Efektivitas Badan Pengawas Pada Non Performing Loan. E-Jurnal Akunatnsi Universitas Udayana, 13(3), 779-795.

Dewi, P., K. Mulyadi, M. dan Abdurrakhman, A. (2015). Analisis Pengaruh CAR, NPL, LDR Dan NIM Terhadap Profitabilitas Perbankan. Jaffa, 3(1), 17-30.

Fajari, S. \& Sunarto. (2017). Pengaruh CAR, LDR, NPL, BOPO Terhadap Profitabilitas Bank (Studi Kasus Perusahaan Perbankan yang Tercatat di Bursa Efek Indonesia Periode Tahun 2011 sampai 2015). Prosiding Seminar Nasional Multi Disiplin Ilmu dan Call For Papers Unisbank Ke 3, Universitas Stikubank, Semarang, Juli 2017, 853-862.

Kasmir, (2008). Analisis Laporan Keuangan. Jakarta: PT. Raja Grafindo Persada.

Kasmir, (2014). Analisis Laporan Keuangan, Edisi Pertama, Cetakan Ketujuh. Jakarta: Penerbit PT. Raja Grafindo Persada.

Pinasti W., F. \& Mustikawati RR., I. (2018). Pengaruh CAR, BOPO, NPL, NIM, dan LDR terhadap Profitabilitas Bank Umum Periode 2011-2015. NOMINAL, 7(1), 126-142.

Peraturan Otoritas Jasa Keuangan Nomor 4 Tahun 2016 Tentang Penilaian Tingkat Kesehatan Bank Umum.

Peraturan Bank Indonesia Nomor 17/11/PBI/2015 Tentang Perubahan Atas Peraturan Bank Indonesia Nomor 15/15/PBI/2013 Tentang Giro Wajib Minimum Bank Umum Dalam Rupiah dan Valuta Asing Bagi Bank Umum Konvensional.

Peraturan Bank Indonesia Nomor 15/7/PBI/2013 Tentang Perubahan Kedua Atas Peraturan Bank Indonesia Nomor 12/19/PBI/2010 Tentang Giro Wajib Minimum Bank Umum Pada Bank Indonesia Dalam Rupiah dan Valuta Asing.

Siamat, D. (2005). Manajemen Lembaga Keuangan Kebijakan Moneter dan Perbankan, Edisi ke 5. Jakarta: Fakultas Ekonomi Universitas Indonesia. 
Sugiyono. (2013). Metode Penelitian Pendidikan. Bandung: Alfabeta.

Surat Edaran Bank Indonesia Nomor 6/23/DPNP/2004 Perihal Sistem Penilaian Tingkat Kesehatan Bank Umum.

Surat Edaran Bank Indonesia Nomor 13/23/DPNP/2011 Perihal Perubahan atas Surat Edaran No. 5/21/DPNP Perihal Penerapan Manajemen Risiko Bagi Bank Umum.

Surat Keputusan Direktur Bank Indonesia No.30/12/KEP/DIR/1997 tentang Tata Cara Penilaian Tingkat Kesehatan Bank Umum. Jakarta: Bank Indonesia.

Surat Edaran Bank Indonesia Nomor 30/2/UPPB Tanggal 30 April 1997 Tentang Tatacara Penilaian Tingkat Kesehatan Bank Umum.

Surat Edaran BI No. 30/3/UPPB Tanggal 30 April 1997 Tentang Tata Cara Penilaian Tingkat Kesehatan Bank Perkreditan Rakyat.

Taswan. (2010). Manajemen Perbankan Konsep, Terknik, dan Aplikasi. Yogyakarta: UPP STIM YKPN. Undang-Undang Perbankan Nomor 10 tahun 1998 Tentang Perubahan Atas Undang-Undang Nomor 7 Tahun 1992 Tentang Perbankkan.

www.idx.co.id data perusahaan perbankkan diakses pada tanggal 1 Desember 2020 Pkl 07.00 WIB 